\title{
Engendering Change in the UDA: Gary Mitchell's Loyal Women
}

\author{
By Wesley Hutchinson \\ Université Paris 3-Sorbonne Nouvelle
}

\begin{abstract}
Copyright (c) 2005 by Wesley Hutchinson. This text may be archived and redistributed in electronic form, provided that the author and journal are properly cited and no fee is charged for access. Archiving, redistribution, or republication of this text on other terms, in any medium, requires the notification of the journal and consent of the author.
\end{abstract}

\begin{abstract}
Gary Mitchell's most recently published play, Loyal Women, continues his systematic exploration of the Ulster loyalist mindset, focusing this time on the role of women within the UDA. Whereas on the face of it, the play moves forward through what are presented as a series of sharp, irreconcilable oppositions - UDA/IRA, women/men, domestic/public, inside/outside - it emerges in the end that the fundamental organising principle behind the play, and by extension behind the paramilitary society it represents, is rather that of refraction, or more precisely, replication. As a result, any potential for evolution, individual or collective, is quickly subsumed into an apparently inescapable logic of duplication and repetition. In a profoundly pessimistic reading of post-Agreement Northern Irish society, Mitchell focuses on the embedded nature of a culture of violence and in the process presents an intimate, first-hand reading of the tensions within contemporary loyalist paramilitarism.
\end{abstract}

Key Words: Gary Mitchell, UDA, women, paramilitarism, loyalism, Northern Ireland, Protestant

Since he started writing for the theatre in the early 1990s, the controversial young playwright, Gary Mitchell has been exploring in a methodical, almost inquisitorial manner, the various institutions that give expression to or interact with the life of the Protestant, working-class, loyalist community in Northern Ireland to which he belongs. Thus, over the past few years he has turned his attention to the Orange Order and the issue of contested parades (Marching $\mathrm{On}^{1}$ ), to the Royal Ulster Constabulary and its reform (The Force of Change $^{2}$ ) and to the prison system in the North $\left(\right.$ Holding Cell $\left.{ }^{3}\right)$. But the main institution to which he returns regularly, almost obsessively, is the Ulster Defence Association (UDA ${ }^{4}$ ), the largest loyalist paramilitary organisation in Northern Ireland. In plays like Trust $t^{5}$ and $A s$ the Beast Sleeps ${ }^{6}$ the organisation forms the context to and principal agent of the action. In these plays he looks at various aspects of the organisation's activities, both legal (political and social involvement) and illegal ("punishment beatings", "protection", etc.). In his most recently published play, Loyal Women, ${ }^{7}$ he returns again to this paramilitary organisation, the attention this time being on its women's branch, the WUDA. This choice is perhaps not fortuitous. We think of Grania McFadden's caustic remark in the Belfast Telegraph concerning Marching On: "Mitchell still fails to write convincing parts for women", a rare piece of criticism in the chorus of praise that generally attends his work. Whether or not one agrees with McFadden's analysis it is tempting to see the play's specific focus on women as an exercise in rectifying this alleged imbalance while at the same time allowing him to push his systematic investigation of every nook and cranny of the loyalist world one stage further. 
The play, concerns the activities of a branch of the Women's UDA (WUDA) ${ }^{9}$ in Rathcoole, a Protestant housing estate in the north of Belfast where Mitchell himself lives. It explores the power struggle within a small group of women: Maureen, the person in charge of the unit who is about to retire from the organisation; Gail, a younger, extremely violent woman in her thirties who hopes to take over when Maureen retires; Heather, a "boot-girl", Gail's henchwoman; Brenda, the central character of the play, a long-standing member of the organisation who, some sixteen years earlier, had murdered an IRA woman on the orders of the UDA, but who has subsequently sought to move away from her violent past; and Jenny, her daughter, a teenage single mother, who, in spite of her mother's opposition, wants to join the organisation. The focus of the play concerns another young Protestant woman, Adele, who is going out with a Catholic from the Falls Road, a republican stronghold in West Belfast. The young man has been seen in Rathcoole and, given his background, the UDA suspect he may be collecting information for the IRA. The UDA therefore sub-contract the problem to the women's branch and instruct them to "have a chat" with Adele in order to ensure that the relationship is broken off.

The central question is the means by which this end is to be achieved. Whereas the traditionalists within the group, especially Gail and Heather, favour the use of intimidation, backed up with an unambiguous demonstration of force, Brenda, the pentita, favours dialogue and persuasion. This tension between violence and dialogue, between the practices of the past and the expectations of the post-Good Friday Agreement present, is one of the fundamental issues in the play.

The situation is further complicated by the breakdown in Brenda's relationship with her husband, Terry, a member of the UDA who has just been released from prison after serving sixteen years of a life sentence, having admitted to the murder that Brenda had in fact committed. On his release from prison - most probably under the terms of the Good Friday Agreement - Terry gets drunk and sleeps with Heather, a one-night stand that is enough to have Brenda throw him out of the house. The sexual politics of Brenda's turbulent relationship with Terry, and with another, more recent acquaintance, Mark, constitutes a counterpoint to the strategic and ideological positioning within the women's organisation.

The action of the play takes place in one 24-hour period in Brenda's council house on the Rathcoole estate. The stage area is divided in two, the "living room" where most of the action takes place, and the "parlour" which has been converted into a bedroom for Rita, Brenda's bed-ridden mother-in-law whom she is looking after.

Whereas on the face of it, the play moves forward through what are presented as a series of sharp, irreconcilable oppositions UDA/IRA, women/men, domestic/public, inside/outside - it emerges in the end that the fundamental organising principle behind the play, and by extension behind the paramilitary society it represents, is rather that of refraction, or more precisely, replication. As a result, any potential for evolution, individual or collective, is quickly subsumed into an apparently inescapable logic of duplication and repetition. In a profoundly pessimistic reading of postAgreement Northern Irish society, Mitchell focuses on the embedded nature of a culture of violence and in the process presents an intimate, first-hand reading of the tensions within contemporary loyalist paramilitarism.

\section{Fundamental patterns}

The key to an understanding of the underlying organising patterns of the play lies in the treatment of space, one of Mitchell's central preoccupations. The fundamental assumption in the play is that space cannot be neutral; it has to "belong" to one religion or the other. ${ }^{10}$ Unsurprisingly, conversation in the play takes it for granted that the urban space of Belfast is divided up into a clearly defined network of "estates" which are under the control of a particular paramilitary organisation. The central aspect here is that, from a paramilitary perspective, space should ideally be exclusive. The higher the degree of ethnic uniformity within a given area, the greater the potential for paramilitary control. This basic reality explains why members of the other community must be excluded.

What is important is that this pattern of exclusion is seen as being common to both sides. In other words, Mitchell's work is thankfully - not simply yet another sermon on loyalist paranoia and the Protestant "siege mentality". While the UDA seeks to exclude the young Catholic, Adele, his Protestant 
girlfriend, states in a matter-of-fact way that she is "not allowed in his estate" (58). When she complains of this, she is told: "You shouldn't want to go to his fucking estate" (58). Gail, in one of her typically clinical speeches, provides further detail:

GAIL ... Your parents don't allow you to go up there. [Y] our dad runs you everywhere... The reason he doesn't run you up The Falls is because he knows like we know that The Falls is not safe for Protestants... Unlike The Falls where they would rape you and kill you as soon as they found out you were from here the men of Rathcoole have not done that to him, in fact they've tried to help him. They didn't touch him. They didn't intimidate him. They merely tried to protect him by telling him he can't come here while he is under suspicion of these offences against our community. (61-62)

Movement between one area and another is seen as abnormal and places the person so engaged under suspicion, if not actually under threat. Anyone attracting someone from the other community into their area is seen at best as deviant, at worst, as a fifth columnist - a "Lundy" in Protestant parlance- threatening the community from within. Each side therefore seeks to patrol its own territory. Exclusion replicates exclusion.

This fundamental, binary division of space into "loyalist" and "republican" territory, is replicated within the particular economy of the play in what emerges as a subsidiary gendering of space. However, the space the women create for themselves is one carved out of existing Protestant space. It is not additional to or separate from that space. In so far as it is an integral part of that initial Protestant heartland it must obey the same basic rules. It is hardly surprising therefore that we should find that social relations within this subsidiary space function along the same binary patterns as the prototype from which it derives.

The action of the play takes place exclusively inside Brenda's house. This domestic space is clearly placed under exclusively female control. The house itself is home to three women and a baby girl linked together in a tight intergenerational network: Brenda, her mother-in-law, her daughter and her grand-daughter. Women are shown as being able to move freely in and out of the house. For example, despite the fact that Brenda repeatedly tries to protest, she has to resign herself to her house being used as the focal point for the local branch of the Women's UDA: "They're having a meeting here tonight" (9). Later, Maureen simply strolls into the house, announcing casually: "The door was open" (78). Women are clearly free to move into, out of and around this space at will.

On the other hand, the presence of men in the house is clearly provisional, always subject to negotiation and dependent entirely on Brenda's approval. Terry, the husband from whom she is separated, has to bargain his way into what had once been his own house by convincing his daughter to lend him a key; he is constantly being told to leave and at one point is informed that he "... won't be getting back into this house" (84). As regards the only other man in the play, Mark, Brenda's new "partner", whom she never invites to stay, Brenda tells Terry on his release from prison: "I could have moved him in any time" (74). Just as the paramilitary organisations control the right of entry into their respective estates, so Brenda determines the conditions in which men enter and leave what is clearly female territory.

The microcosm of the house is therefore seen as reproducing the macrocosm of Northern Irish society. Brenda's domestic space spontaneously structures itself according to the same underlying binary pattern. Exclusion therefore replicates exclusion even within the closed circle of ethnic space.

However, the principle of replication goes well beyond the issue of space. Indeed, we find that some of the female characters in the play push the logic so far as to seek to turn themselves into what amounts to clones of men. Just as they are shown to be content merely to produce carbon copies of male social patterns, women take on all the -most brutal - characteristics of their male prototypes. Such cloning is particularly evident in relation to the use of language-as-threat. The play is littered with brash, assertive warnings framed with abrasive humour, as when Brenda suggests she could have Terry killed, or more probably that she could do it herself:

TERRY: Go and live with this

Whoremaster? Over my dead body.

BRENDA: That can be arranged. (75)

The women's mastery of the language codes hitherto reserved to men is such that they do 
not hesitate to mock men's hypocritical taboos regarding supposed limits to their violence:

TERRY: I've never hit a woman in my life but you are coming very, very close to it. BRENDA: Go ahead and see what happens to you (76)

In this mirroring of codes, this reproduction of a single behavioural model, Mitchell even goes as far as to suggest that there has been a reversal of the roles, that the clone is so perfect that it is beginning to displace the original:

TERRY: This is my house you're standing in and that's my wife you're talking to.

GAIL: Put me out of it then

TERRY: If you weren't a woman.

GAIL: You mean if you weren't a woman.

TERRY freezes completely uncertain as to what to do next. (36)

However the reality of violence, like space, is seen as gendered, and is directed inward, against other women. In this closed world, light years away from any lingering images we may have of "peace women", women display a limitless potential for violence against other women. Interestingly, the weaker women in the play seek to protect themselves by laying claim to a source of power exercised by proxy through family connections - specifically gendered family connections, in which the male continues to play the supposed role of protector. Thus, while Rita seeks to defend herself by playing on her son's street creed: "My son Terry['s] a very big man - top man in the UDA just out of jail" (8), Adele challenges her attackers saying: "You can't touch me. My uncle's in the police" (67). However, the other women, the ones Mitchell is really interested in, are capable of ignoring such warnings. Referring specifically to these supposed networks of male protection, Brenda at one point actually tells her husband: "I've been alone here without your protection for a very long time" (28). Indeed, everyone on the estate knows that she is a murderer. Despite the fact she is determined to leave her violent past behind, she constantly uses her kudos as a one-time killer to fend off any possible threat: "You really don't want to know what I can or cannot do, Jenny" (86). Mitchell shows in his explicitly realistic, sitcom style that women have no hesitation in translating this potential into reality. Hence the unambiguous nature of the stage directions that make the women's capacity for violence crystal clear: "GAIL punches ADELE in the kidneys. This stuns ADELE." (50); "ADELE hits HEATHER in the side of the head with an ornament." (53); "GAIL punches ADELE in the side. ADELE is stunned. GAIL punches her again very hard on the opposite side. ADELE keels over..." (63); "HEATHER and JENNY pour the tar over ADELE. ADELE screams as it burns into her hair, head and skin" (100).

Despite the brutality of the humour, despite the intensity of the violence of which women are capable, it quickly emerges that women's autonomy from men is fundamentally illusory. Ultimately, men are seen as retaining control. Their anonymous, invisible power is felt throughout the play. There is never any question of the Women's UDA emerging as a separate, autonomous power base, never any possibility of any form of gynarchy. On the contrary, it is clear that the WUDA exists as an integral, subordinate part of the men's organisation, in much the same way as the women's lodges of the Orange Order fit in to the broader structure under men's control. In the end, the clone exists for the benefit of its prototype.

It is clear, for example, that the women's actions are determined by decisions taken by men. It is they who initiate action: the men want us to "have a chat with Adele" (18). Likewise, it is understood that if the women do not produce a satisfactory result, the men will take over: "They wanted to send her up to one of their punishment squads" (90); the older women know that men can "ruin that wee girl's life" (90), or again that, "[t]he men will take over and they will do really bad things to you" (97). It is as if we were to understand that women are capable of taking on an individual man but not the men's organisation as a whole. ${ }^{11}$ The extent of that control is such that, without even consulting the women concerned, the men are capable of deciding which of the women is to take over from Maureen:

MAUREEN: [Gail]'s not the friendly, sociable, politically correct face that they want. She scares people. She scares most men for flip sake.

BRENDA You always need a strong leader, especially one who could stand up to the men.

MAUREEN. No they won't let it happen. (79)

It emerges that the men have decided to refuse Gail in favour of Brenda, the reason 
being that, while Gail "scares people", Brenda is seen as more "politically correct". Clearly, the organisation is conscious of a need for a change of image. Brenda's past behaviour and present attitude are seen as supplying a suitable narrative to exemplify that change.

\section{Women as vectors of change}

The issue as to which of the women has the support of the organisation has to be read within the context of the peace process in Northern Ireland. Mitchell began writing plays in the 1990s at a time when the various loyalist paramilitary organisations were going through far-reaching internal debate. Following the model that had been laid down by the republican movement which had sought with greater or lesser success- to shift emphasis away from armed struggle towards political action, loyalism in the 1990s began to question its exclusively military orientation. Like the Provisionals, the two major paramilitary organisations within loyalism, the UVF (Ulster Volunteer Force) and the UDA (Ulster Defence Association) sought to move away from violence in favour of a political role within a more complex, less monolithic unionism. Of the two organisations, the UDA was the first to embark on that attempted politicisation through the work of the NUPRG (New Ulster Political Research Group ${ }^{12}$ ) which sought to construct an ideological framework in which the UDA might take on a more political role within the Protestant working class community. The political party to emerge as a result, the UDP (Ulster Democratic Party ${ }^{13}$ ), was to play a key role alongside the PUP (Progressive Unionist Party), the UVF's political wing, in negotiating the Good Friday Agreement of 1998.

It was of central importance to London and Dublin that there should be input from the Protestant paramilitaries, and this for several reasons. First and foremost, their active participation was vital in that, like Sinn Féin, they kept open lines of communication with the gunmen. They also shared many of Sinn Féin's preoccupations not only on sensitive areas like decommissioning and prisoner release, but also on questions relating to the social deprivation that was and remains common to many of the working class urban areas from which they obtained their support, questions such as poor housing, unemployment, drug addiction and urban violence. The presence of the loyalist paramilitaries at the negotiating table was vital to the success of the deal in that it allowed the governments - who were conscious of the high level of hostility from within mainstream unionism - to show that concessions on the thorny issues of decommissioning and prisoner release were not concessions to the Provisional IRA in that they satisfied loyalist demands as well. Most importantly, the terrorists-turnedpoliticians were living proof that change was possible. The representatives of these new parties, people like Gusty Spence ${ }^{14}$ for the PUP, and Ray Smallwoods ${ }^{15}$ for the UDP, had chosen to abandon violence and to enter the arena of democratic politics. However, after the heady days of Easter 1998, the transition from military machine to political movement was to be as difficult for loyalism as it has been for republicanism.

Mitchell's analysis of this aspect of the peace process has always been marked by deep cynicism. In a play like As the Beast Sleeps, he examines many of the practicalities of this transition from armed struggle to political debate. Mitchell explains:

I wrote it in an ocean of optimism. The ceasefire was six weeks old and everyone on television made a point of saying that the war was over and that there was peace in Northern Ireland. It was dreadful to see world leaders shaking hands and saying that everybody was going to get on from now on. ${ }^{16}$

As the Beast Sleeps focuses on resistance within the UDA to the political line taken up by the elite within the organisation. It shows the pressures that develop within the movement when "dissidents" refuse to follow the new strategy and decide to continue their campaign of violence, determined to keep up the war against the enemy they had been programmed to fight, Irish republicanism. Since the dissidents refuse to be deprogrammed, Mitchell shows how the UDA's only recourse is to bring them into line through the use of force. Without the slightest trace of irony, punishment squads are set up within the organisation to beat the dissidents into compliance with the new "non-violent" line. In other words, the transition to "exclusively democratic means", one of the mantras of the Good Friday Agreement, is by no means simple. As the title of the play suggests, the "beast" of paramilitary violence is only asleep. 
Within the context of Loyal Women, this ongoing debate on the possibility of change within loyalist paramilitarism crystallises round the figures of Gail and Brenda.

Brenda is a source of interest to the paramilitary organisation because she has shown herself to be capable of change. As a young woman, she had joined the UDA and had been involved in the murder of an IRA woman. ${ }^{17}$ However, she has undergone a profound change in her behaviour in that she is now seen as seeking solutions to problems through dialogue and compromise. Rather than imposing conformity through the use of violence, her overriding objective is now to avoid violence at all costs. Her mastery of language-as-threat is designed to ensure that violence can be replaced with persuasion. This desire to avoid violence fits in with the subtext of the paramilitaries' shift from armed struggle to dialogue. From the point of view of the paramilitary godfathers, she therefore emerges as a possible model for change.

Information filtering down from the UDA hierarchy makes it clear that those in charge disapprove of Gail's more violent approach since it is likely to lead to the organisation getting bad press. Although Gail applies to succeed Maureen as head of the local Women's branch, Brenda is told that a vote has been taken at county level and that she is to take over, despite the fact she had never sought any responsibility in the organisation. The explanation Maureen gives Brenda is clear: "Gail hasn't changed and never will. You have" (79). Brenda's strategy is put to the test when she is given the task of convincing Adele to give up her Catholic boyfriend.

However, through his treatment of this theme, Mitchell shows that we are not to understand that the UDA is in the throes of a fundamental re-think of its position. The organisation's interest in Brenda has more to do with public relations, with image, than with root-and-branch reform. Ultimately, dialogue, persuasion is not seen as an autonomous alternative to violence. As was the case with As the Beast Sleeps, dialogue is in fact only an element in a broader strategy of control which does not hesitate to envisage the use of violence if talking does not succeed. In other words, Brenda, despite her good intentions, is seen as unwittingly reinforcing the position of the paramilitary structures in that she offers the possibility of producing the desired effect - obedience, conformity to the wishes of the paramilitary hierarchy - through a softlysoftly strategy that would demonstrate the organisation's conversion to "exclusively peaceful means". However, it is clear that at no point in the play do any of the characters, except perhaps the victim herself, think that the organisation will tolerate any questioning of its initial decision to separate Adele and her Catholic lover. In other words, Brenda is being invited to prove to the community that her strategy can produce the desired result - the recuperation of the "deviant" woman, the purification of the ethnic space of the estate, and the maintenance of the status quo. If she can, she will become an icon of change, living proof that paramilitarism can operate successfully through dialogue, thus satisfying the theoretical, non-violent minima of the new political dispensation. However, concretely, the paramilitaries will continue to maintain control over what they consider "their" territory, "their" community. It is understood that if she fails, "the men will take over". Either way, the interests of the organisation will be safeguarded.

The problem is that the nature of the evolution in Brenda's thinking is more radical than those in charge of the organisation think. In a rare reference to the woman she was ordered to murder sixteen years before, Brenda says:

I didn't know if she was in the IRA or not. I just took [the UDA's] word for it because I was young and I believed them. I was a teenager like you. A real head-banger but I grew up and I learned things - like how to prioritise. I used to have a list it read like this: Ulster, the Queen, Britain and fuck everything else but I changed that list to me, my mum, my daughter and her daughter and that's the way it will stay. (85)

The speech's importance goes well beyond the immediate context of the play. Brenda's questioning of the validity of the instructions she received, her critical assessment of her naivety supposes a distancing from the organisation which she had seen as defending her Protestant identity and sense of Britishness. The grounds of her self-criticism, i.e. her unthinking acceptance of her organisation's analysis, and her total, uncritical commitment to a faceless political leadership, mirror precisely what loyalist politicians - the spokesmen for the paramilitary 
organisations - had identified as the root causes of the subservience of the loyalist working class vis-à-vis traditional Unionism. Political analysis coming out of loyalist paramilitary circles in the mid and late 1990s claimed that the Unionist establishment during the Stormont period had demanded a total unquestioning loyalty on the part of the loyalist working class which it allegedly manipulated into supporting the status quo by threatening that any split in the "unionist monolith" would be exploited by nationalists and would lead to the collapse of the Union. Protestant workingclass support for the Unionist establishment did not, it was claimed, necessarily translate into any particular social benefits for that Protestant working-class. Traditional unionism was therefore denounced as having been classbased and entirely self-interested. What we witness in the play is that the logic of criticism is being pushed one stage further. Here, it is the paramilitary leadership - a new "loyalist establishment" - that is coming in for criticism from the members of the community which had hitherto given it their unquestioning support.

Fundamentally, Brenda's attempt to move away from violence is presented as involving a rejection of the political in favour of the personal. Interestingly, within the terms of reference of the play, her re-centring on the personal produces a gendered vision of history that focuses exclusively on the notion of intergenerational commitment in the female line: "me, my mum, my daughter and her daughter".

This focus poses a number of problems. A large part of the organisation's power consists precisely in its ability to abolish the border between the private and the public spheres among the people under its control. This is made clear in the highly public nature of discussion of what in a normal society would be intimate, personal matters. The obvious example is Adele's affair which becomes a matter of concern for the entire community. Brenda's wonderful speech - a pure Mills and Boon classic - is delivered in front of the kangaroo court made up of the local women members of the UDA:

BRENDA: Do you love him?... If you love this guy with all your heart. I mean truly, deeply, with every fibre of your being. If you are willing to give up your life for his then I need to know about it right now. Is this guy the one? Does your heart race when you see him? Does it miss a beat when you kiss? Is there ever a moment in the day when you don't think about him? (66)

Given this level of collective interference in an individual's personal relationships, it is hardly surprising that the notion of privacy is a non-starter. Indeed there is a sense that there is no private space; the community's right to investigate and to decide for one of its members is seen as non-negotiable. The public and the private are co-extensive. Given the impossibility of distinguishing between the domestic and the public spheres, Brenda's switch towards the family, to a form of history read in terms of biological linkages along an exclusively female line, her attempt to re-write identity and history as gendered genealogy, represents too much of a challenge to the established paramilitary, male-centred order. Ultimately, Brenda's choice is synonymous with withdrawal. Because change is so difficult to achieve "inside" the organisation, the only solution lies "outside". It is precisely that desire for secession that constitutes the most serious threat to paramilitary power.

At the end of the play, Mitchell shows us that pressures within paramilitary society are so great that Brenda reverts to violence. Having attempted to protect Adele from the consequences of her actions, having succeeded in the end in extracting a promise that she would stop going out with her Catholic boyfriend, the other members of the kangaroo court - Heather and her own daughter Jenny who has been mobilised for the occasionpour boiling tar over the head of "the accused" and cover her in feathers as a sign of her treachery to the Protestant community. Enraged at the pointlessness of this punishment, at Jenny's growing involvement in the organisation and at Heather's relentless sniping, Brenda loses control, "takes the knife from the chair and sticks it in HEATHER. HEATHER tumbles back and falls against the wall" (103). In an exceptionally intense exchange, Brenda, still holding the knife, addresses Gail in the only language she understands - the language of violence:

BRENDA (to Gail): You want to sort this whole thing out right now just between you and me; I'm happy with that. You want to involve other people, go and get yourself some backup; I'm OK with that too. But if you want to walk out that door and get on with your life without ever having to think 
about me, let me know now that I don't ever have to worry about you and we'll call it a day and forget about each other. Because if you want to go to war with me; I'll give you a war and every single person that you ever loved, every friend you ever had and every member of your family will never ever be safe again. (104)

Playing on the principle within paramilitary society which refuses to recognise any difference between the personal and the public, Brenda unexpectedly and unilaterally pulls the locus of her confrontation with Gail into the personal domain. This placing of the personal, the individual in hyper-focus has the effect of detaching Gail from her power base - the organisation. She becomes a target, "the" target, for personal, not political reasons. And as far as Brenda is concerned, Gail will remain the target, no matter what the organisation may or may not do. This affirmation of the personal redefines the balance in their relationship, one that is clearly now to Brenda's advantage. Unlike Gail, Brenda has shown herself to be capable of murder. If she can kill on the orders of the UDA, she can kill just as easily for her own ends.

We do not know whether Gail will accept Brenda's offer of armed peace - the play ends brutally with the stage direction: "GAIL considers her options. Blackout". However, we do know that Northern Ireland has seen the alternative acted out in its streets in the murderous feuds that have been raging between various paramilitary factions within the loyalist community since 2000 . Given that Mitchell's theatre is so closely tuned in to developments within that community, it is difficult not to imagine such parallels. ${ }^{18}$ Brenda's vision of an all-out, highly personalised and above all internal war can easily be read as a veiled reference to the ongoing turf wars involving such high-profile figures as the former UDA commander, Johnny Adair ${ }^{19}$ — vendettas inseparable from networks of family and friends ${ }^{20}$ - and which have produced a UDA that is clearly "cannibalising itself". 21

Whichever route Gail chooses to go down, the analysis, as far as Northern Ireland is concerned, is profoundly pessimistic. The only result that the experiment in change is seen to have produced is the hope that Brenda might be able to prise herself —and perhaps her immediate family - out of the grip of the UDA. Far from being an alternative pattern for the future, Brenda's exit strategy leaves the fundamental binary structuring of her society intact: her withdrawal from the organisation means that her strategy of dialogue and persuasion is in ruins and that Gail - and her ilk - will be in control of the UDA. In its portrayal of the resistance to change within contemporary loyalism, the play therefore augurs ill for the hope that paramilitarism will soon be in a position to settle down to the practice of "exclusively peaceful means".

\section{Notes}

1. Marching On opened at Belfast's Lyric Theatre in June 2000. Unpublished.

2. The Force of Change, London, Nick Hern Books, 2000. First produced at the Royal Court Theatre in London, April 2000.

3. Holding Cell was part of a series of seven short plays by different authors, performed at Crumlin Road Courthouse in October 2000 and presented in: Convictions, Belfast, Tinderbox, 2000.

4. For an analysis of the role of the UDA in the Northern Protestant Community, see James McAuley, The Politics of Identity: A Loyalist Community in Belfast, Aldershot, Avebury, 1994. For an "inside history" of the UDA, see Prisoners' Aid and Post-Conflict Resettlement Group, A Brief History of the UDA/UFF in Contemporary Conflict, Belfast, 1999. For the most recent history of the UDA, see Henry McDonald and Jim Cusack, UDA: Inside the Heart of Loyalist Terror, London, Penguin, 2004.

5. Trust. London, Nick Hern Books, 1999. First produced at the Royal Court Theatre, March 1999.

6. As the Beast Sleeps, London, Nick Hern Books, 2001, was written in 1994 and had its first production at The Abbey, Dublin, in June 1998. It was subsequently adapted as a film for television: Dir. Harry Bradbeer. Prod. Tony Rowe. Perf. Stuart Graham, Patrick O’Kane, Laine McGan, Daniel O’Grady, Colum Convey. BBC Northern Ireland. 2001.90 mins.

7. The play's first performance was at the Royal Court Jerwood Theatre Downstairs, London, 5 November to 13 December, 2003. 
8. Grania McFadden, "Mitchell's 'marching season' lacks edge and menace”. The Belfast Telegraph, 14 June, 2000.

9. Mitchell's focus on the Women's UDA is all the more intriguing in that the organisation was for a long time dormant. Indeed, after the involvement of some of its members in the murder of a fellow WUDA member in 1974 the organisation was stood down. See, Rosemary Sales, "Gender and Protestantism in Northern Ireland", in Peter Shirlow and Mark McGovern (eds), Who are 'The People?, London, Pluto Press, 1997, 148. A Brief History of the UDA/UFF in Contemporary Conflict (Belfast, Prisoner's Aid and Post-Conflict Resettlement Group, 1999) makes no reference to the WUDA as such. However, it contains a section entitled "Women's Action" (50-52) in which it explains that a group of that name was created at the beginning of the Troubles to lobby for Political Status for loyalists and that:

[w] ithin the Women's Action, there was also a group who directly involved themselves in active service on behalf of the UDA. They were used as couriers to move weaponry, supply "safe" houses and on many occasions, were directly involved in all aspects of paramilitary activity.

However, the text concludes:

From the mid " 80 "s onwards the role of Women's Action diminished and their numbers declined. The structure of their organisation has almost fallen apart although they still function - albeit without the structure that was so effective previously. There is not the same formal link with the UDA/UFF.

For interview material on loyalist women see: E Fairweather, R. McDonough and M. McFadyean, Only The Rivers Run Free: Northern Ireland, The Women's War, London, Pluto, 1984, chapter entitled, "The Cover of the Wings of the Almighty Jehovah: Protestant Women in Belfast".

10. For a brief history of segregation in Belfast, see P. Doherty and M.A. Poole, Ethnic Residential Segregation in Belfast, Coleraine, Centre for the Study of Conflict, 1995.

11. Referring to he 1974 decision to stand down the WUDA, Rosemary Sales (op. cit. 148) explains: "While punishment of women who transgress has been tolerated among the Loyalist community, the fact that it was women, acting on their initiative, who carried out this particularly brutal murder may have contributed to the condemnation of the Women's UDA" (my emphasis).

12. The New Ulster Political Research Group has been one of the most dynamic think-tanks to have emerged from the loyalist community. It produced a number of important policy documents, most notably, Beyond the Religious Divide (1978) and Common Sense (1987), which argued for the creation of an independent Ulster. The Group was behind the creation of a political party, The Ulster Democratic Party (UDP), designed to channel the political aspirations of the UDA.

13. Having played a significant role in the talks process, the UDP, led by Gary McMichael, failed to live up to expectations in the elections to the Northern Ireland Assembly after the Agreement. Subsequent tensions within the UDA led to the UDP's decision to disband in November 2001.

14. For a biography of Gusty Spence, see Roy Garland, Gusty Spence, Belfast, The Blackstaff Press, 2001.

15. Smallwoods was murdered by the IRA in July 1994.

16. "Processed peace: Gary Mitchell's Protestant play ethic", Time Out, September 12-19, 2001.

17. Brenda's alleged involvement in a murder runs contrary to the received wisdom that, within loyalism, women were not given roles as "operatives". However, the exact nature of loyalist women's involvement in paramilitary activity remains murky to say the least. One interviewee in E Fairweather, R. McDonough and M. McFadyean, Only The Rivers Run Free: Northern Ireland, The Women's War, London, Pluto, 1984, 304, claimed:

Of course there are women in the UDA and the UFF. I remember two years ago the UDA wanted to start trouble for the IRA on the Falls, UDA women carried guns on to the Falls, and some men fired at the army to make it look like the IRA had done it. A woman UDA brigadier brought the guns back to the Shankill UDA centre. They only say there are no women so they can use them as decoys.

18. See, for example, Callie Persic and Stephen Bloomer, The Feud and the Fury, Belfast, Springfield Intercommunity Development Project, 2001.

19. See, for example, "Shots fired at loyalist terrorist's funeral", The Guardian, February 6, 2003.

20. Brenda demonstrates her understanding of the mechanisms of the vendetta-style thinking within loyalist circles. Within the context of the ongoing power struggle inside the UDA, one of the primary figures, Johnny Adair, former leader of the notorious « $\mathrm{C} »$ Company of the UDA in West Belfast, in an interview with The Observer, referred to the victimisation to which his associate, John White, was exposed by members of a rival faction within the UDA : "They have attacked John White's home and were prepared to put his children's lives in danger", in Henry McDonald, "Adair pours scorn on UDA death threats", The Observer, 15 December, 2002. Adair's own family subsequently became the targets of internecine violence: "The feud between loyalist 
terrorists in Northern Ireland erupted on the streets of England yesterday when a gunman fired at the house where Johnny Adair's wife had taken refuge with their children...". D. Lister and R. Jenkins, "Loyalist feud hits England", The Times, May 1, 2003.

21. This expression "an institution cannibalising itself" was used by Robert Gore-Langton, The Express, 23 April 2000 in relation to Mitchell's portrayal of the RUC in Marching On. The comment is reminiscent of Mitchell's comments several years ago concerning Protestantism: "the danger now is that it's becoming divided up, like this fragmented monster fighting with itself more often than its enemies, or its perceived enemies", The Irish Times, 25 February 1998. 